\title{
PENGARUH SALINITAS TERHADAP PERTUMBUHAN, BIOMASSA DAN KLOROFIL-a DUNALIELLA SP.
}

\author{
Muhammad Fakhria,b*, Laksmana Wisnu ${ }^{\mathrm{a}}$, Arning Wilujeng Ekawati ${ }^{\mathrm{a}}$ \\ aProgram Studi Budidaya Perairan, Fakultas Perikanan dan Ilmu Kelautan Universitas Brawijaya, \\ J1. Veteran, Malang, Indonesia \\ ${ }^{\text {b} K e l o m p o k ~ K a j i a n ~ A q u a t i c ~ B i o f l o c, ~ F a k u l t a s ~ P e r i k a n a n ~ d a n ~ I l m u ~ K e l a u t a n ~ U n i v e r s i t a s ~ B r a w i j a y a, ~}$ \\ Jl. Veteran, Malang, Indonesia
}

*Koresponden penulis : mfakhri@ub.ac.id

\begin{abstract}
Abstrak
Dunaliellasp. merupakan mikroalga hijau yang kaya beta karoten dan klorofil, bersifat euryhaline, dan telah banyak dimanfaatkan untuk budidaya ikan dan udang. Salah satu strategi yang dilakukan untuk meningkatkan produktivas mikroalga adalah dengan melakukan optimasi kondisi lingkungan. Salinitas merupakan faktor esensial yang mempengaruhi pertumbuhan dan kandungan biokimia Dunaliella. Tujuan penelitian ini adalah untuk menjelaskan pengaruh salinitas yang berbeda dan menentukan salinitas terbaik untuk pertumbuhan, produksi biomassa, dan klorofil-a Dunaliella sp. Salinitas yang berbeda yaitu 5 ppt, 15 ppt, 25 ppt, dan 35 ppt digunakan pada penelitian ini. Hasil dari penelitian ini menunjukkan bahwa salinitas yang berbeda berpengaruh terhadap pertumbuhan, produksi biomassa, dan klorofil-a Dunaliella sp. ( $\mathrm{p}<0,05)$. Salinitas terbaik untuk pertumbuhan, produksi biomassa, dan klorofil-a Dunaliella sp. diperoleh pada salinitas $15 \mathrm{ppt}$ yang menghasilkan konsentrasi sel maksimum sebesar $9,86 \times 10^{6} \mathrm{sel} / \mathrm{ml}$, biomassa 0,52 $\mathrm{g} / \mathrm{l}$, dan klorofil-a 11,26 mg/l. Laju pertumbuhan yang tinggi berhubungan dengan biomassa dan kandungan klorofil-a Dunaliella sp. Dapat disimpulkan bahwa salinitas yang berbeda memberikan pengaruh signifikan terhadap pertumbuhan, produksi biomassa, dan klorofil-a Dunaliella sp. Disarankan menggunakan salinitas 15 ppt untuk menghasilkan pertumbuhan, produksi biomassa, dan klorofil-a Dunaliella sp. yang optimal.
\end{abstract}

Kata kunci: euryhaline, konsentrasi sel, laju pertumbuhan spesifik, mikroalga hijau, salinitas

\begin{abstract}
Dunaliella sp. is a euryhaline green microalga that is a source of beta carotene and chlorophyll and has been widely applied in fish and shrimp cultivation. One of the strategies to improve microalgae productivity is by optimizing environmental conditions. Salinity is one of the essential parameters that remarkably influence the growth and biochemical content of Dunaliella. The aim of this study was to explain the effect of different salinity and determine the best salinity for growth, biomass production, and chlorophyll-a of Dunaliella sp. Different salinities of $5 \mathrm{ppt}, 15 \mathrm{ppt}, 25 \mathrm{ppt}$, and $35 \mathrm{ppt}$ were used in this study. The results of this study indicated that salinity affects growth, biomass production, and chlorophyll-a content of Dunaliella sp. $(\mathrm{p}<0.05)$. The best salinity for growth, biomass production, and chlorophyll-a content of Dunaliella sp. was obtained at a salinity of $15 \mathrm{ppt}$ which resulted in a maximum cell concentration of $9.86 \mathrm{x}$ $10^{6}$ cells $/ \mathrm{ml}$, biomass $0.52 \mathrm{~g} / \mathrm{l}$, and chlorophyll-a $11.26 \mathrm{mg} / \mathrm{l}$. The high growth rate is related to the biomass and chlorophyll-a content of Dunaliella sp. It can be concluded that salinity has a significant effect on growth, biomass production, and chlorophyll-a Dunaliella sp. It is recommended to use a salinity of $15 \mathrm{ppt}$ for optimal growth and chlorophyll a content of Dunaliella sp.
\end{abstract}

Keywords: euryhaline, cell concentration, green microalgae, salinity, specific growth rate

\section{PENDAHULUAN}

Mikroalga adalah mikroorganisme autotrof, yang memanfaatkan energi cahaya dan nutrisi anorganik (karbondioksida, nitrogen, fosfor) untuk menghasilkan biomassa [1]. Dalam akuakultur, mikroalga dimanfaatkan sebagai pakan alami untuk larva ikan, udang dan kerang karena mengandung asam lemak tak jenuh misalnya, asam eicosapentaenoic (EPA), asam arakhidonat dan asam docosahexaenoic (DHA) [2]. Dunaliella sp. merupakan mikroalga hijau (Chlorophyta) uniseluler [3] 
dan memiliki kandungan protein $57 \%$, lemak $6 \%$, karbohidrat $32 \%$ [4]dan total karoten 0,19 ppm [5]. Selain itu, [6] menjelaskan bahwa Dunaliella merupakan tiga sumber produk penting yaitu gliserol, $\beta$-karoten, dan protein.

Faktor lingkungan seperti cahaya, nutrisi, suhu, $\mathrm{pH}$ dan salinitas mempengaruhi pertumbuhan dan komposisi kimia mikroalga [7]. Salinitas merupakan salah satu faktor paling penting yang mempengaruhi pertumbuhan, produktivitas mikroalga [8], [9], dan kandungan pigmen mikroalga [10].

Adaptasi dari setiap mikroalga terhadap salinitas adalah spesies-spesifik dan tergantung pada karakteristik fisiologis spesies [11]dan asal spesies [12]. [13] melaporkan bahwa salinitas berpengaruh terhadap pertumbuhan dan pigmen Dunaliella sp. [14] mengungkapkan bahwa Chlorella sp. menunjukkan pertumbuhan optimum ketika dikultur pada salinitas rendah. Akan tetapi, [15] melaporkan bahwa pertumbuhan $D$. viridis meningkat dengan meningkatnya salinitas.

Dunaliella merupakan organisme fotosintesis dominan di banyak lingkungan garam dan dapat beradaptasi dengan hampir seluruh rentang salinitas (euryhaline) [16] dari 10 hingga 50 ppt [17]. Namun, kisaran salinitas yang optimum menjadi faktor penting dalam pertumbuhan dan perkembangan Dunaliella sp. Oleh karena itu, diperlukan penelitian untuk menentukan salinitas terbaik untuk menghasilkan produksi biomassa dan klorofil a Dunaliella sp. yang optimal.

\section{METODE}

\section{Strain dan Media Pertumbuhan Mikroalga}

Bibit Dunaliella sp. diperoleh dari kultur murni Balai Besar Riset Perikanan Budidaya Laut (BBRPBL) Gondol, Bali. Media yang digunakan adalah air laut dengan menggunakan pupuk Walne dan vitamin.

Stok Dunaliella sp. dikultur pada erlenmeyer $500 \mathrm{ml}$ dengan media $300 \mathrm{ml}$ air salinitas 15 ppt dengan menggunakan pupuk Walne $1 \mathrm{ml} / \mathrm{l}$. Penyediaan inokulan Dunaliella sp. dilakukan selama 4 hari hingga fase logaritmik. Proses kultur inokulan dilakukan pada suhu $28^{\circ} \mathrm{C}$ dengan intensitas cahaya 4.500 lux, lama penyinaran 24:0 siklus terang/gelap dan dilakukan aerasi secara kontinyu.

\section{Rancangan Penelitian}

Penelitian ini menggunakan Rancangan Acak Lengkap (RAL) dengan salinitas yang berbeda yaitu $5,15,25$ dan $35 \mathrm{ppt}$ dan pengulangan sebanyak 3 kali. Penentuan salinitas dilakukan dengan cara mengencerkan air laut hingga mencapai salinitas yang diinginkan. Setiap perlakuan diulangsebanyak 3 kali. Dunaliella sp. dikultur dengan konsentrasi awal sel $2 \times 10^{5}$ $\mathrm{sel} / \mathrm{ml}$, pada suhu $28 \pm 2^{\circ} \mathrm{C}$, lama penyinaran 24:0 siklus terang/gelap, intensitas cahaya 4.500 lux dan dilakukan aerasi secara terus menerus. Pengukuran konsentrasi sel dilakukan setiap hari sedangkan analisa biomassa dan klorofil-a dilakukan ketika sel mencapai konsentrasi sel tertinggi.

\section{Analisis Pertumbuhan}

Perhitungan konsentrasi sel Dunaliella sp. dilakukan menggunakan metode penghitungan konsentrasi sel menggunakan 0,1 mm deep Neubauer haemocytometer.

Laju pertumbuhan spesifik dianalisa dengan menggunakan rumus dari [15] yaitu:

$\mu=\frac{\ln x 2-\ln x 1}{t 2-t 1}$

dimana $\mu$ merupakan laju pertumbuhan spesifik (/hari) kultur, $\mathrm{x}_{1}$ dan $\mathrm{x}_{2}=$ konsentrasi sel pada waktu ke-1 $\left(\mathrm{t}_{1}\right)$ dan waktu ke-2 $\left(\mathrm{t}_{2}\right)$, berturut-turut.

\section{Analisis Biomassa}

Sampel mikroalga yang digunakan untuk analisis biomassa diperoleh Ketika mikroalga mencapai konsentrasi sel maksimal. Kertas saring GF/C (diameter 90 $\mathrm{mm}$ ) dioven pada suhu $105^{\circ} \mathrm{C}$ selama 2 jam hingga beratnya konstan (A). Sampel suspensi mikroalga $25 \mathrm{ml}$ difilter melalui kertas saring GF/C dan dicuci dengan $25 \mathrm{~mL}$ akuades untuk menghindari kontaminasi garam. Kemudian kertas saring dioven pada suhu $105^{\circ} \mathrm{C}$ selama 2 jam. Setelah dingin, kertas saring diletakkan di desikator selama 30-60 menit, kemudian beratnya ditimbang kembali (B) [18].

Berat kertas saring $=\mathrm{A}$ 
Berat kertas saring + alga $\quad=\mathrm{B}$ Berat kering/biomassa $(\mathrm{g} / \mathrm{l}) \quad=$ $[B]-[A] \times 1000$

Volume sampel

\section{AnalisisKlorofil}

Klorofil-a dianalisa dengan menggunakan modifikasi metode [19] dan [20]. Diambil $5 \mathrm{ml}$ sampel tabung/falcon yang steril dan dibungkus alumunium foil tertutup rapat. Disentrifugasi $5 \mathrm{ml}$ kultur mikroalga pada $6.000 \mathrm{rpm}$ selama 10 menit dan dibuang supernatan dilakukan proses freezing-thawing masing-masing 15 menit (hingga membeku dan mencair) selama 3 siklus dan ditambahkan $5 \mathrm{ml}$ metanol absolut pada pellet, dipanaskan pada suhu $70^{\circ} \mathrm{C}$ selama 15 menit, divortex sampai homogen. Diinkubasi pada suhu $4^{\circ} \mathrm{C}$ dalam keadaan gelap selama 24 jam. Sampel divortex dan dilakukan sentrifugasi $6.000 \mathrm{rpm}$ selama 10 menit. Kemudian diambil supernatan untuk diukur dengan menggunakan spektrofotometer pada panjang gelombang $665 \mathrm{~nm}$ dan $652 \mathrm{~nm}$. Perhitungan klorofil a $(\mathrm{mg} / \mathrm{l})$ menurut [21]:

Chl a $=-8,0962 \times 0 D 652+16,5169 \times 0 D 665$

\section{Analisis Data}

Data dianalisis menggunakan uji oneway ANOVA dan uji BNT melalui SPSS 16. Selang kepercayaan yang digunakan $\mathrm{p}<0,05$.

\section{HASIL DAN PEMBAHASAN}

\section{Pengaruh Salinitas yang Berbeda terhadap Pertumbuhan dan Biomassa}

Data laju pertumbuhan, konsentrasi sel maksimum, dan produksi biomassa Dunaliella sp. pada salinitas 5, 15, 25, dan 35 ppt dapat dilihat pada Tabel 1. Hasil penelitian menunjukkan bahwa salinitas yang berbeda berpengaruh terhadap laju pertumbuhan sel dan produksi biomassa Dunaliella sp. $(\mathrm{p}<0,05)$. Laju pertumbuhan spesifik dan konsentrasi sel maksimum tertinggi diperoleh pada perlakuan salinitas 15 ppt yaitu masing-masing sebesar 0,77 /hari dan $9,86 \times 10^{6} \mathrm{sel} / \mathrm{ml}$ sedangkan yang terendah dihasilkan pada salinitas 5 ppt yaitu dengan nilai masing-masing sebesar 0,68 /hari dan $3,89 \times 10^{6} \mathrm{sel} / \mathrm{ml}$. Peningkatan salinitas dari 5 menjadi 15 ppt meningkatkan pertumbuhan Dunaliella sp., akan tetapi jika salinitas ditingkatkan hingga $35 \mathrm{ppt}$ menyebabkan konsentrasi sel dan laju pertumbuhan menjadi menurun. Selain itu, pola yang sama juga diamati pada produksi biomassa Dunaliella sp. pada salinitas yang berbeda. Biomassa Dunaliella sp. pada salinitas 5, 25, dan 35 ppt lebih rendah dibandingkan salinitas 15 ppt. Hasil menunjukkan bahwa 15 ppt merupakan salinitas terbaik untuk pertumbuhan dan biomassa Dunaliella sp., walaupun mikroalga dapat tumbuh dengan baik pada salinitas lainnya.

Hasil pada penelitian ini sesuai dengan yang dilaporkan oleh beberapa peneliti sebelumnya yaitu pada salinitas lebih dari 15 ppt akan terjadi penurunan pertumbuhan dan produksi biomassa, hal ini serupa dengan respon dari Synechococcus sp., dan Dunaliella salina terhadap salinitas tinggi [22], [23]. Adaptasi dari setiap mikroalga terhadap salinitas adalah spesies-spesifik dan tergantung pada karakteristik fisiologis spesies [11] dan asal spesies [12]. Pada penelitian ini semakin tinggi salinitas menyebabkan pertumbuhan akan terhambat, hal ini sesuai dengan pernyataan [24], bahwa dengan meningkatnya konsentrasi garam dalam medium, kerja sel Dunaliella menjadi lebih terhambat sehingga hampir tidak ada reaksi berlangsung dalam sitoplasma pada salinitas tinggi, hanya proses pembentukan gliserol yang tetap aktif dalam sel. Dunaliella menyesuaikan tekanan osmotik melalui metabolism gliserol intraseluler [25]. [26] menambahkan bahwa mikroalga akan mengeluarkan energi lebih banyak Ketika mencoba untuk mempertahankan tekanan turgor, dan ini mengakibatkan penurunan produktivitas atau penurunan pertumbuhan. Respon mikroalga terhadap perubahan salinitas diatur dalam dua tahap. Tahap pertama ditandai dengan perubahan yang cepat dalam tekanan turgor atauperubahan volume yang disebabkan oleh fluktuasi air yang masuk atau keluar dari organisme mengikuti gradien osmotik. Tahap kedua merupakan penyesuaian konsentrasi sel sampai mencapai keadaan stabil. 
Tabel 1. Laju pertumbuhan spesifik, konsentrasi sel maksimum dan biomassa Dunaliella sp. pada salinitas yang berbeda

\begin{tabular}{|c|c|c|c|c|}
\hline \multirow{2}{*}{ Parameter } & \multicolumn{4}{|c|}{ Salinitas (ppt) } \\
\hline & 5 & 15 & 25 & 35 \\
\hline $\begin{array}{l}\text { Laju } \\
\text { pertumbuhan } \\
\text { spesifik (/hari) }\end{array}$ & $\begin{array}{l}0,59 \pm 0,01 \\
\text { a }\end{array}$ & $\begin{array}{l}0,77 \pm 0,02 \\
\mathrm{c}\end{array}$ & $\begin{array}{l}0,72 \pm 0,01 \\
\text { b }\end{array}$ & $\begin{array}{l}0,68 \pm 0,01 \\
\text { b }\end{array}$ \\
\hline Biomassa (g/l) & $\begin{array}{l}0,36 \pm 0,43 \\
\text { a }\end{array}$ & $\begin{array}{l}0,53 \pm 0,01 \\
\mathrm{~d}\end{array}$ & $\begin{array}{l}0,47 \pm 0,02 \\
\text { c }\end{array}$ & $\begin{array}{l}0,41 \pm 0,01 \\
\mathrm{~b}\end{array}$ \\
\hline $\begin{array}{l}\text { Konsentrasi } \\
\text { sel maksimum } \\
\left(\text { ( 10 } 10^{6} \mathrm{sel} / \mathrm{ml}\right)\end{array}$ & $\begin{array}{l}3,89 \pm 0,26 \\
\text { a }\end{array}$ & $\begin{array}{l}9,86 \pm 0,64 \\
d\end{array}$ & $\begin{array}{l}7,32 \pm 1,21 \\
\mathrm{c}\end{array}$ & $\begin{array}{l}6,41 \pm 0,73 \\
\text { b }\end{array}$ \\
\hline
\end{tabular}

\section{Pengaruh Salinitas yang Berbeda Terhadap Kandungan Klorofil-a}

Kandungan klorofil Dunaliella sp. pada salinitas yang berbeda dapat dilihat pada Gambar 1. Hasil mengindikasikan bahwa salinitas yang berbeda berpengaruh signifikan terhadap kandungan klorofil-a Dunaliella sp. $\quad(\mathrm{p}<0,05)$. Peningkatan salinitas dari 15 menjadi $35 \mathrm{ppt}$ mengakibatkan penurunan kandungan klorofil-a sebesar 32,65\% dengan konsentrasi klorofi-a $(11,27 \mathrm{mg} / \mathrm{l})$ tertinggi dihasilkan pada salinitas 15 ppt. Hasil ini sesuai dengan [27], yang menemukan bahwa konsentrasi klorofil menurun ketika salinitas ditingkatkan dari 25 ppt menjadi 35 ppt pada Nannochloropsis oculata. [28] juga melaporkan bahwa salinitas yang rendah menghasilkan kandungan klorofil-a tertinggi pada Tetraselmis chuii. [29] menjelaskan bahwa konsentrasi klorofil berhubungan dengan konsentrasi sel mikroalga, dimana semakin tinggi konsentrasi sel menghasilkan nilai klorofil yang tinggi.

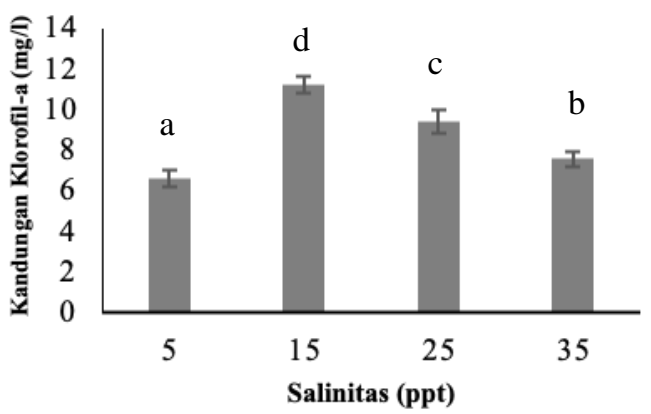

Gambar 1. Kandungan klorofil-a Dunaliella sp. pada salinitas yang berbeda

\section{KESIMPULAN}

Optimasi salinitas merupakan factor utama untuk meningkatkan produksi mikroalga. Hasil penelitian menunjukkan bahwa 15 ppt merupakan salinitas terbaik untuk pertumbuhan, produksi biomassa, dan klorofil-a Dunaliella sp.

\section{UCAPAN TERIMA KASIH}

Peneliti mengucapkan terima kasih kepada Fakultas Perikanan dan Ilmu Kelautan, Universitas Brawijaya atas dukungan dana penelitian.

\section{DAFTAR PUSTAKA}

[1] M. Janssen, "Cultivation of microalgae: effect of light / dark cycles on biomass yield," Unpubl. Master's thesis Wageningen Univ. Wageningen Netherlands, vol. 1191, no. 2006, p. 184, 2002.

[2] K. I. Reitan, J. R. Rainuzzo, G. Øie, and Y. Olsen, "A review of the nutritional effects of algae in marine fish larvae," Aquaculture, vol. 155, no. 1-4, pp. 207-221, 1997, doi: 10.1016/S0044-8486(97)00118-X.

[3] M. A. Borowitzka, Dunaliella: Biology, Production, and Markets. 2013.

[4] E. W. 1994. Becker, "Microalgae Biotechnology and Microbiology," p. p 177-180., 1994.

[5] R. Darsi, S. Agus dan D. S. Ade, "Karakteristik Kimiawi dan Potensi Pemanfaatan Dunaliella salina dan Nannochloropsis sp," no. 1996, pp. 14-25, 2012.

[6] L. Dufossé et al., "Microorganisms and microalgae as sources of pigments for food use: A scientific oddity or an industrial reality?," Trends Food Sci. Technol., vol. 16, no. 9, pp. 389-406, 2005, doi: 10.1016/j.tifs.2005.02.006.

[7] W. J. Henley, K. M. Major, and J. L. Hironaka, "Response to salinity and 
heat stress in two halotolerant chlorophyte algae," J. Phycol., vol. 38, no. 4, pp. 757-766, 2002, doi: 10.1046/j.1529-8817.2002.01172.x.

[8] M. Fakhri, N. B. Arifin, B. Budianto, A. Yuniarti, and A. M. Hariati, "Effect of salinity and photoperiod on growth of microalgae Nannochloropsis sp. and Tetraselmis sp.," Nat. Environ. Pollut. Technol., vol. 14, no. 3, pp. 563-566, 2015.

[9] M. Fakhri, N. B. Arifin, A. Yuniarti, and A. M. Hariati, "The influence of salinity on the growth and chlorophyll content of Nannochloropsis sp. BJ17," pp. 15-18, 2017.

[10] A. K. Cowan and P. D. Rose, "Abscisic acid metabolism in saltstressed cells of Dunaliella salina: Possible interrelationship with $\beta$ carotene accumulation," Plant Physiol., vol. 97, no. 2, pp. 798-803, 1991, doi: 10.1104/pp.97.2.798.

[11] A. Richmond and E. W. Becker, "Handbook of Microalgal Mass Culture," Handbook of Microalgal Mass Culture (1986). pp. 245-264, 1986.

[12] S. Banerjee, W. E. Hew, H. Khatoon, and M. Shariff, "Growth and proximate composition of tropical marine Chaetoceros calcitrans and Nannochloropsis oculata cultured outdoors and under laboratory conditions," vol. 10 , no. 8 , pp. 13751383, 2011.

[13] L. A. Loeblich, "Photosynthesis and pigments influenced by light intensity and salinity in the halophile Dunaliella Salina (Chlorophyta)," J. Mar. Biol. Assoc., vol. 62, no. 3, pp. 493-508, 1982.

[14] N. S. Adenan, F. M. Yusoff, and M. Shariff, "Effect of salinity and temperature on the growth of diatoms and green algae," J. Fish. Aquat. Sci., vol. 8, no. 2, pp. 397-404, 2013, doi: 10.3923/jfas.2013.397.404.
[15] I. Ak, T. Goksan, and S. Cirik, "Effect of light intensity, salinity and temperature on growth in Camalt1 strain of Dunaliella viridis Teodoresco from Turkey," J. Biol. Sci., vol. 8, no. 8, pp. 1356-1359, 2008.

[16] U. Pick, "Adaptation of the Halotolerant Alga Dunaliella to High Salinity," Salin. Environ. - Plants Mol., pp. 97-112, 2006, doi: 10.1007/0-306-48155-3_5.

[17] H. Khatoon et al., "Effects of different salinities on the growth and proximate composition of Dunaliella sp. isolated from South China Sea at different growth phases," Process Saf. Environ. Prot., vol. 112, pp. 280-287, 2017, doi: 10.1016/j.psep.2017.04.010.

[18] M. Janssen et al., "Specific growth rate of Chlamydomonas reinhardtii and Chlorella sorokiniana under medium duration light/dark cycles: 13-87 s," Progress in Industrial Microbiology, vol. 35, no. C. pp. 323-333, 1999, doi: 10.1016/S0079-6352(99)80124-6.

[19] A. Bennet and L. Bogorad, "Complementary chromatic adaptation in a filamentous blue-green alga. Journal of Cell Biology. 58: 419-435.," J. Cell Biol., vol. 58, pp. 419-435, 1973, doi: 10.1016/S00223468(89)80710-9.

[20] H. K. Lichtenthaler, "Chlorophylls and carotenoids: Pigments of photosynthetic biomembranes," $J$. Methods Enzymol., vol. 148, pp. 350382, 1987.

[21] R. J. Ritchie, "Consistent sets of spectrophotometric chlorophyll equations for acetone, methanol and ethanol solvents," Photosynth. Res., vol. 89, no. 1, pp. 27-41, 2006, doi: $10.1007 / \mathrm{s} 11120-006-9065-9$.

[22] N. Rosales, J. Ortega, R. Mora, and E. Morales, "Influence of salinity on the growth and biochemical composition of the Cyanobacterium Synechococcus 
sp," Ciencias Mar., vol. 31, no. 2, pp. 349-355, 2005, doi: 10.7773/cm.v31i2.59.

[23] M. Takagi, Karseno, and T. Yoshida, "Effect of salt concentration on intracellular accumulation of lipids and triacylglyceride in marine microalgae Dunaliella cells," J. Biosci. Bioeng., vol. 101, no. 3, pp. 223-226, 2006, doi: 10.1263/jbb.101.223.

[24] K. Frank, G. Wegmann, "Physiology and biochemistry of glycerol biosynthesis in Dunaliella.," Biol. Zent. Bl., vol. 93, pp. 707-723, 1974.

[25] D. S. Kessley and A.D. Brown, "Salt relations of Dunaliella: transitional changes in glycerol content and oxygen exchange reactions on water stress," Microbiol., vol. 129, pp. 154-159, 1981.

[26] G. O. Kirst, "Salinity tolerance of eukaryotic marine algae," Annu. Rev. Plant Physiol. Plant Mol. Biol., vol. 41, no. 1, pp. 21-53, 1990, doi: 10.1146/annurev.pp.41.060190.000321

[27] N. Gu, Q. Lin, G. Li, Y. Tan, L. Huang, and J. Lin, "Effect of salinity on growth, biochemical composition, and lipid productivity of Nannochloropsis oculata CS 179," Engineering in Life Sciences, vol. 12, no. 6. pp. 631-637, 2012, doi: 10.1002/elsc.201100204.

[28] F. Ghezelbash, T. Farboodnia, R. Heidari, and N. Agh, "Biochemical effects of different salinities and luminance on Green Microalgae Tetraselmis chuii," Res. J. Biol. Sci., vol. 3, no. 2, pp. 217-221, 2008.

[29] A. Matos, M. Junior, E. B. Neto, M. L. Koening, and E. Eskinazi, "Chemical compositon of three microalgae species for possible use in mariculture," vol. 50, pp. 461-467, 2007. 